\title{
ANALISIS TRANSHIPMENT PASAL 69 AYAT (3) PERATURAN MENTERI KELAUTAN PERIKANAN NO. 30 TAHUN 2012 TENTANG USAHA PERIKANAN TANGKAP
}

\author{
Amelya Gustina \\ Pusat Penelitian dan Pengembangan Kejaksaan Agung RI \\ E_mail: amelya.gustina0808@gmail.com
}

\begin{abstract}
This study aims to analyze the content analysis of the application of Article 69 paragraph (3) of the Regulation of Minister of Marine Affairs and Fisheries No. 30 Year 2012 on Business fisheries in Regional Fisheries Management of the Republic of Indonesia to Indonesian marine fisheries. Previous studies or research focused on handling of legal issues and marine fisheries which was only viewed from the macro side perspective while this research mainly discusses transshipment as stipulated in Article 69 paragraph (3) Regulation of the Minister. It employed normative juridical method by qualitative-descriptive approach. The results showed that the application of the article led to an increased possibility of the practice of IUU fishing by foreign vessels in Indonesian waters, hence, $a$ review of the implementation of the Article is necessarily conducted.
\end{abstract}

Keywords: content analysis, marine fisheries, transhipment

\section{Abstrak}

Studi ini dimaksudkan untuk mengkaji isi Pasal 69 ayat (3) Peraturan Menteri Kelautan dan Perikanan Nomor 30 Tahun 2012 tentang Usaha Perikanan Tangkap di Wilayah Pengelolaan Perikanan Negara Republik Indonesia terhadap perikanan laut Indonesia. Hal ini menjadi penting karena kajian ataupun penelitian sebelumnya mengenai penanganan permasalahan hukum perikanan hanya dilihat pada sisi makro saja, dan kajian ini mengkhususkan pada transhipment sebagaimana diatur dalam Pasal 69 ayat (3) Peraturan Menteri tersebut. Metode penelitian yang digunakan adalah yuridis normatif dengan pendekatan deskriptif kualitatif. Hasil penelitian menunjukan bahwa penerapan Pasal tersebut mengakibatkan semakin besarnya peluang terjadinya praktek IUU Fishing oleh kapal asing di Perairan Indonesia, sehingga perlu dilakukan peninjauan kembali terhadap pemberlakuan Pasal tersebut.

Kata kunci: anasilis isi, perikanan laut, transhipment

\section{Pendahuluan}

Indonesia memiliki wilayah laut teritorial seluas 3.2 juta $\mathrm{km}^{2}$, dengan garis pantai sepanjang $95.181 \mathrm{~km}^{2}$ serta 2.9 juta $\mathrm{km}^{2}$ laut perairan Zona Ekonomi Eksklusif (ZEE), dengan demikian total wilayah perairan Indonesia adalah 77\% dari seluruh luas Indonesia. Potensi geografis inilah yang menjadi dasar menetapkan kebijakan untuk menjadikan Indonesia menjadi Negara Maritim. Putera ${ }^{1}$ mencatat setidaknya

Prakoso Bhairawa Putera, "Perspektif dan Peran IImu Pengetahuan dan Teknologi dalam Membangunan Kemandirian Bangsa Pada Tatanan Negara Maritim", Inovasi: Jurnal Politik dan Kebijakan, Vol 10 No. 2 Edisi ada lima hal yang perlu dimiliki dalam membangun kemandirian tersebut. Pertama, character building and nation building sebagai bangsa yang memiliki orientasi pembangunan negara dari land based oriented National Development menuju ke Archipelagic Based Oriented National Development; kedua, strategi ekonomi keluar dari keterpurukan dengan menjadikan sektor kelautan dan perikanan sebagai sektor andalan (leading sector); ketiga, konsistensi implementasi; keempat, lingkungan sosial

Juni 2013, Medan: Balitbang Provinsi Sumatera Utara, hlm. 139. 
dan politik yang kondusif; dan kelima, low enforcement dan pengamanan wilayah laut.

Muhamad Karim, ${ }^{2}$ menegaskan bahwa dalam pengembangan perikanan dan kelautan di Indonesia, terutama terkait dengan potensi pada pulau-pulau kecil haruslah memperhatikan kesejahteraan masyarakat. Hal ini haruslah diarahkan untuk berbasiskan "dual economics", revitalisasi dan konstruksi kelembagaan, dan demokratisasi lokal berbasis nilai dan kearifian lokal. Ayub Torry Satriyo Kusumo menambahkan, ${ }^{3}$ bahwa penguatan kelembagaan pemerintah yang diikuti dengan kerjasama antara pusat dan daerah, diharapkan mampu memberikan perhatian dan pengelolaan yang lebih baik terhadap pulau-pulau tersebut.

Saat ini, dari 14 zona fishing ground dunia, tinggal 2 zona yang masih potensial. Satu dari dua fishing ground yang masih potensial tersebut merupakan perairan Indonesia. Untuk itu, pada sektor perikanan Indonesia memiliki potensi yang sangat besar. Data Badan Pusat Statistik hingga September 2012 menunjukkan, sedikitnya 40 produk asal ikan impor merupakan komoditas ikan yang dapat ditangkap dan dibudidayakan di Indonesia. Sebagian besar be-rupa produk ikan beku, segar, kering dan diasinkan, seperti udang, cumi-cumi, tuna, tongkol, lemuru, dan kerang. Potensi sumberdaya perikanan baik perikanan tangkap, budidaya laut, perairan umum dan lainnya diperkirakan mencapai US\$ 82 miliar per tahun. Potensi perikanan tangkap mencapai US\$ 15,1 miliar per tahun, potensi budidaya laut sebesar US\$ 46,7 miliar per tahun, potensi peraian umum sebesar US\$ 1,1 miliar per tahun, potensi budidaya tambak sebesar US\$ 10 miliar per tahun, potensi budidaya air tawar sebesar US\$ 5,2 miliar per tahun, dan potensi bioteknologi kelautan sebe-

2 Muhamad Karim, "Partisipasi Daerah dalam Mengantisipasi Ancaman Perubahan Iklim Bagi Eksistensi Pulaupulau Kecil Terluar", Jurnal Pembangunan Daerah, Vol 2009 No. 03 Edisi September 2009, Jakarta: Dirjen Bina Pembangunan Daerah, Departemen Dalam Negeri, hlm. 13.

3 Ayub Torry Satriyo Kusumo, "Optimalisasi Pengelolaan dan Pemberdayaan Pulau-pulau Terluar dalam Rangka Mempertahankan Keutuhan Negara Kesatuan Republik Indonesia", Jurnal Dinamika Hukum, Vol 10 No. 3, Edisi September 2010, Purwokerto: Fakultas Hukum, Universitas Jenderal Soedirman, hlm. 336. sar US\$ 4 miliar per tahun ${ }^{4}$. Berdasarkan data Kementerian Kelautan dan Perikanan (KKP) nilai ekspor perikanan Indonesia dari tahun ke tahun cenderung meningkat. Ditahun 2011 nilai ekspor perikanan Indonesia mencapai 2,5 millar USD dan ditahun 2012 meningkat menjadi 2,8 milliar USD.

Beberapa tantangan yang muncul ditengah potensi perikanan yang dimiliki Indonesia seperti adanya Praktek Illegal, Unreported and Unregulated (IUU) Fishing. Secara sederhana, Illegal fishing berarti penangkapan ikan secara illegal/pencurian ikan. Unreported fishing adalah kegiatan yang menyangkut penangkapan ikan walaupun secara legal namun tidak dilaporkan. Dalam Unreported fishing terdapat juga dua hal yaitu: terdapat kesalahan dalam pelaporannya (misreported) dan pelaporan yang tidak semestinya dan unregulated fishing adalah kegiatan perikanan yang tidak diatur oleh Negara bersangkutan. ${ }^{5}$ IUU Fishing merupakan masalah laten yang dihadapai bangsa ini. Setiap tahun, sumberdaya kita di bombardir Negara lain. Ditambah lagi beberapa perairan di Indonesia telah mengalami over fishing. Beberapa perairan di Indonesia yang tengah berada pada lampu merah atau over fishing antara lain laut Jawa, Samudra Hindia dan laut Sumatera.

Penyebab IUU Fishing sangat kompleks mulai dari luas peraian Indonesia yang besar, keamanan yang lemah dan nelayan kecil yang tak mampu menjangkau sumberdaya ikan di laut bebas. Luas perairan yang besar ditambah adanya pengamanan yang lemah dari pemerintah menjadi jalan masuk terjadinya IUU Fishing. Pengamanan yang lemah ini dikarenakan armada yang dimiliki Indonesia dalam menjaga keamanan perairan sangat minim. Selain itu rendahnya jangkauan nelayan diperairan lepas

Ridwan Lasabuda, "Pembangunan Wilayah Pesisir dan Lautan dalam Perspektif Negara Kepulauan Republik Indonesia', Jurnal Ilmiah Platax, Vol I-2, Edisi Januari 2013, Fakultas Perikanan dan Ilmu Kelautan, Universitas Sam Ratulangi, hlm. 92-101.

5 Dikdik Mohamad Sodik, "IUU Fishing and Indonesia's Legal Framework for Vessel Registration and Fishing Vessel Licensing", Ocean Development \& International Law, Vol 40 Issue 3, 2009, Taylor \& Francis Online, hlm. 249-267. 
menjadikan sumberdaya yang dimiliki Indonesia tidak bisa termanfaatkan makasimal.

Kendala dalam pemberantasan IUU Fishing disebabkan oleh kurang memadainya instrumen hukum Undang-undang Nomor 31 Tahun 2004 tentang Perikanan tidak terdapat pasal yang memberikan hak dalam proses pemeriksaan di laut kepada aparat penegak hukum. Kondisi ini diperparah dengan lemahnya penegakan hukum dan lambatnya penyelesaian kasus per kasus yang telah ditangani oleh aparat penegak hukum mulai dari penyidikan, penuntutan dan putusan pengadilan ${ }^{6}$. Alfons Zakaria mencatat kelemahan ini terjadi karena tumpang tindih peraturan yang ada di Indonesia sehingga penerapan sanksi pidana di ZEE adalah bertentangan tidak hanya terhadap peraturan perundang-undangan yang ada di Indonesia tetapi juga hukum laut internasional. ${ }^{7}$

Akibat praktek IUU Fishing ini, Kepala Pusat Analisis Kerjasama Internasional dan Antar Lembaga, Sekretariat Jenderal Kementerian Kelautan dan Perikanan (KKP) Anang Noegroho menyebutkan, rata-rata selama satu dekade terakhir negara mengalami kerugian sebesar Rp 30 triliun pertahun dari pencurian oleh negara asing. Jika mengambil standar penjualan ikan dunia, harga satu kilogram ikan adalah 2 dolar, artinya ikan yang dicuri 166 ton pertahun. Bahkan Éva Plagányia, ${ }^{8}$ menyebut IUU Fishing sebagai problematik terbesar dalam dunia perikanan internasional.

Di tengah kondisi perikanan Indonesia yang kritis ini, Menteri Kelautan dan Perikanan mengeluarkan Peraturan Menteri Kelautan dan Perikanan Nomor 30 Tahun 2012 tentang Usaha Perikanan Tangkap di Wilayah Pengelolaan Per-

6 Amelya Gustina, "Pentingnya Pemberantasan Illegal, Unreported and Unregulated (IUU) Fishing Guna Mendukung Pembangunan Wilayah Laut Berkelanjutan", Jurnal Bina Adhyaksa, Vol. 3 No. 3 Edisi Juli 2013, Jakarta: Puslitbang Kejaksaan Agung RI, hlm. 247.

7 Alfons Zakaria, "Imprisonment for IUU Fishing in Indonesia's Exclusive Economic Zone: Why it Should Not Be Imposed", Jurnal "Arena Hukum", Vol 6 No. 2, Edisi Agustus 2012, Malang: Fakultas Hukum, Universitas Brawijaya, hlm. 79.

8 Éva Plagányi,Doug Butterworth,dan Markus Burgener, "Illegal and unreported fishing on abalone-Quantifying the extent using a fully integrated assessment model" Fisheries Research, Vol 107 (2011), Elsevier B.V., hlm. 221-232. ikanan Negara Republik Indonesia, yang mana pada Pasal 69 ayat (3) menentukan, bahwa:

Dalam pelaksanaan transhipment, ikan wajib didaratkan di pelabuhan pangkalan sesuai SIPI atau SIKPI dan tidak dibawa ke luar negeri, kecuali bagi kapal penangkap ikan yang menggunakan alat penangkapan ikan purse seine berukuran diatas 1000 (seribu) GT yang dioperasikan secara tunggal

Peraturan Menteri ini menjadi kontradiktif terhadap kondisi perikanan Indonesia yang rawan praktek IUU Fishing karena mengizinkan kapal pukat cincin berbobot mati 1.000 ton yang beroperasi tunggal untuk menangkap ikan di perairan Indonesia lebih dari 100 mil hingga laut lepas, dan melakukan alih muatan (transhipment) ikan di tengah laut untuk diangkut langsung ke luar negeri.

Praktik transhipment kerap terjadi sepanjang tahun, bahkan di antaranya didaratkan di luar negeri. Hingga 2011 menurut data Badan Statistik, sedikitnya terdapat 6.830 kapal ikan Indonesia yang mendapat izin menangkap ikan di ZEEI. Seluruh kapal tersebut diwajibkan mendaratkan ikannya di Indonesia. Kenyataannya, tindak pidana perikanan masih saja terjadi. Martin Tsamenyi, ${ }^{9}$ menyebutkan bahwa transhipment merupakan salah satu modus pencurian ikan. Modus transhipment artinya pemindahan muatan ikan yang terjadi di tengah lautan lepas dari satu kapal ke kapal asing. Modusnya, kapal itu menjual ikannya di laut lepas tanpa melaporkan hasil tangkapannya, baru pada tangkapan terakhir atau saat periode perizinan hampir berakhir, mereka biasanya melaporkan kepada pejabat yang berwenang di Indonesia. Saat di kapal pun, pencatatan jumlah ikan yang ditangkap tidak dihitung kembali secara cermat. Hal-hal seperti ini menjadi angka rugi yang tersamarkan.

Berdasarkan uraian di atas, terdapat sebuah permasalahan yang diuraikan pada artikel ini, yaitu bagaimana transhipment dilihat dari

\footnotetext{
9 Martin Tsamenyi, et.al, "The European Council Regulation on Illegal, Unreported and Unregulated Fishing: An International Fisheries Law Perspective", The International Journal of Marine and Coastal Law, Vol 25 (2010), Leiden: Koninklijke Brill NV, hlm. 5-31.
} 
perspektif isi Pasal 69 Ayat (3) Peraturan Menteri Kelautan dan Perikanan Nomor 30 Tahun 2012 tentang Usaha Perikanan Tangkap di Wilayah Pengelolaan Perikanan Negara Republik Indonesia Terhadap Perikanan Laut Indonesia. Artikel ini akan membahas tentang implikasi dari suatu peraturan dilihat dari segi keberlakukan peraturan dan kesesuaian dengan asas-asas hukum yang berlaku dan peraturan perundang-undangan terkait menjadi sangat penting. Peraturan Menteri Kelautan dan Perikanan Nomor 30 Tahun 2012 tentang Usaha Perikanan Tangkap di Wilayah Pengelolaan Perikanan Negara Republik Indonesia dan Praktik IUU Fishing di Perairan Indonesia merupakan kajian dalam ranah hukum publik.

Tujuan kajian ini adalah untuk mendalami mengenai isi Pasal 69 Ayat (3) Peraturan Menteri Kelautan dan Perikanan Nomor 30 Tahun 2012 tentang Usaha Perikanan Tangkap di Wilayah Pengelolaan Perikanan Negara Republik Indonesia Terhadap Perikanan Laut Indonesia. Kajian ini menjadi penting dan memiliki signifikan karena selama ini kajian ataupun penelitian pengenai penanganan permasalahan hukum perikanan dan kelautan hanya dilihat pada sisi makro saja, dan kajian ini mengkhususkan pada transhipment (alih muat ditengah laut) untuk alat penangkapan ikan purse seine berukuran diatas 1000 (seribu) GT yang dioperasikan secara tunggal.

\section{Pembahasan}

Kajian ini pada dasarnya merupakan kajian hukum, namun karena membahas suatu produk hasil kebijakan maka istilah "analisis isi" digunakan. Analisis kebijakan tidak hanya dilihat dari pengembangan analisis kebijakan dalam proses kebijakan, tetapi juga analisis kebijakan dari proses kebijakan. ${ }^{10}$ Orientasi ini tidak hanya peduli dengan dampak sosial yang lebih luas dari kebijakan. Akan tetapi ikut

10 Fink-Hafner, D, "The Political Instrumentalisation of Policy Analysis", Journal Politicka Misao: Croatian Political Science Review, Vol 48 No. 5, Tahun 2011, Croatian: Faculty of Policital Science, University of Zagreb, hlm 25-39. memperhatikan isi dari kebijakan itu sendiri. ${ }^{11}$ Isi kebijakan tidak hanya terkait dengan jaringan kelembagaan untuk menciptakan interaksi dalam menjalankan kebijakan publik. ${ }^{12}$ Petak, Z., \& Petek, A., ${ }^{13}$ menyebutkan ada masalah lain terkait dengan isi kebijakan, yaitu penempatan suatu kebijakan tertentu dalam agenda (periode proses kebijakan di mana tujuan dari kebijakan yang dimaksudkan) dan perumusan kebijakan (periode di mana kemungkinan yang berbeda untuk kebijakan dievaluasi). Perumusan kebijakan terkait erat dengan aktor perumus sedangkan penempatan suatu kebijakan terkait dengan content dari kebijakan. Hal ini mengindikasi bahwa isi kebijakan sangat tergantung bagaimana proses dimana berbagai unsur dalam masyarakat menggalang kekuatan dan otoritas, dan mempengaruhi dan mengesahkan kebijakan dan keputusan tentang kehidupan publik, serta pembangunan ekonomi dan sosial. Bentuk keputusan yang dihasilkan oleh aktor (menteri) tersebut biasanya berbentuk peraturan dan keputusan menteri. ${ }^{14}$ Dokumen dari bentuk-bentuk inilah yang kemudian dilakukan identifikasi. Identifikasi (mapping) atas isi kebijakan umumnya dikenal dengan analisis isi, analisis ini menggunakan bingkai dari kebijakan (instrumen kebijakan) di bidang perikanan.

\section{Illegal, Unreported, Unregulated (IUU) Fi- shing dan Transhipment}

11 Prakoso Bhairawa Putera dan Lina Miftahul Jannah, "Science \& Technology and Innovation Policies in Science \& Technological Research, Development, and Implementation", International Journal of Administrative Science \& Organization, Vol 19 No. 2, Edisi September, Tahun 2012, Depok: Departemen Ilmu Administrasi, FISIP - Universitas Indonesia, hlm. 206-215.

12 Prakoso Bhairawa Putera, "Perspektif Sistem Inovasi dalam Konten Kebijakan Daerah Jawa Timur Bidang Iptek dan Inovasi, Periode 2000 - 2011", Jurnal "Warta Kebijakan Iptek dan Manajemen Litbang", Vol 10 No. 2, Edisi Desember, Tahun 2012, Jakarta: Puslit Perkembangan Ilmu Pengetahuan dan Teknologi, Lembaga Ilmu Pengetahuan Indonesia, hlm. 83-98.

13 Petak, Z., \& Petek, A, "Policy Analysis and Croatian Public Administration: The Problem of Formulating Public Policy", Journal Politicka Misao: Croatian Political Science Review, Vol 46 No. 5, Tahun 2009, Croatian: Faculty of Policital Science, University of Zagreb, hlm 54-74.

14 Hall, C., "A typology of governance and its implications for tourism policy analysis", Journal of Sustainable Tourism, 19(4/5) Tahun 2011, hlm 437-457. 
Istilah Illegal, Unreported and Uregulated (IUU) Fishing di Indonesia terdapat pada PERMA No. 1 Tahun 2007 tentang Peradilan Perikanan. Namun pada makalah ini istilah IUU Fishing merujuk pada pengertian yang dikeluarkan oleh International Plan of Action (IPOA) Illegal, Unreported, Unregulated (IUU) Fishing ${ }^{15}$ yang diprakarsai oleh FAO, Ndiaye, ${ }^{16}$ dan Baird. ${ }^{17}$ Pertama, Illegal Fishing adalah kegiatan menangkap ikan yang: (1) dilakukan oleh orang atau kapal asing pada suatu perairan yang menjadi yurisdiksi suatu negara tanpa izin dari negara tersebut atau bertentangan dengan peraturan perundang undangan yang berlaku; (2) bertentangan dengan peraturan nasional yang berlaku atau kewajiban internasional; (3) dilakukan oleh kapal yang mengibarkan bendera suatu negara yang menjadi anggota organisasi pengelolaan perikanan regional, tetapi beroperasi tidak sesuai dengan ketentuan pelestarian dan pengelolaan yang diterapkan oleh organisasi tersebut atau ketentuan hukum internasional yang berlaku.

Kedua, Unreported Fishing atau kegiatan perikanan yang tidak dilaporkan adalah suatu kegiatan penangkapan ikan yang: (1) tidak pernah dilaporkan atau dilaporkan secara tidak benar kepada instansi yang berwenang, tidak sesuai dengan peraturan perundang-undangan nasional; dan (2) dilakukan di area yang menjadi kompetensi organisasi pengelolaan perikanan regional, namun tidak pernah dilaporkan atau dilaporkan secara tidak benar, tidak sesuai dengan prosedur pelaporan dari organisasi tersebut. ${ }^{18}$

15 Food and Agriculture Organisation, 2001 International Plan of Action to Prevent (IPOA), Deter and Eliminate Illegal, Unreported and Unregulated Fishing, Pasal 3.1, Pasal 3.2 dan Pasal 3.3, Rome, hlm 24.

16 Tafsir Malick Ndiaye, "Illegal, Unreported and Unregulated Fishing: Responses in General and in West Africa", Chinese Journal of International Law (2011), Oxford: Oxford University Press, hlm. 373-405.

17 Rachel Baird, "Illegal, Unreported and Unregulated Fishing: An Analysis of The Legal, Economic and Historical Factors Relevant to its Development and Persistence", Melbourne Journal of International Law, Vol 5 (2004). Melbourne: University of Melbourne.

18 Sularso, 2012, Permasalahan IUU Fishing”, Makalah dalam Seminar Permasalahan IUU Fishing, Jakarta: Kejaksaan Agung RI, hlm 3.
Ketiga, Unregulated Fishing atau kegiatan perikanan yang tidak diatur adalah kegiatan penangkapan ikan yang: (1) dilakukan pada suatu area atau stok ikan yang belum diterapkan ketentuan pelestarian dan pengelolaan dan kegiatan penangkapan tersebut dilaksanakan dengan cara yang tidak sesuai dengan tanggungjawab negara untuk pelestarian dan pengelolaan sumber daya ikan sesuai hukum internasional; dan (2) dilakukan pada suatu area yang menjadi kewenangan organisasi pengelolaan perikanan regional, yang dilakukan oleh kapal tanpa kewarganegaraan, atau yang mengibarkan bendera suatu negara yang tidak menjadi anggota organisasi tersebut, dengan cara yang tidak sesuai atau bertentangan dengan ketentuan pelestarian dan pengelolaan dari organisasi tersebut.

IPOA-IUU Fishing telah memberikan batasan terhadap pengertian IUU fishing, namun dalam pengertian yang lebih sederhana dan bersifat operasional. IUU Fishing dapat diartikan sebagai kegiatan perikanan yang melanggar hukum.

Pengaturan mengenai IUU Fishing dapat kita lihat pada beberapa peraturan. Pertama, International Plan of Action, Code of Conduct for Responsible Fisheries; kedua, UU No 17 Tahun 1985 tentang Pengesahan United Nations Convention on the Law of the Sea (UNCLOS); ketiga, UU No. 45 Tahun 2009 perubahan UU No. 31 Tahun 2004 tentang Perikanan, Peraturan Pemerintah No. 54 Tahun 2002 tentang Usaha Perikanan; keempat, Keputusan Menteri Kelautan dan Perikanan Nomor KEP.50/ MEN/2012 tentang Rencana Aksi Nasional Pencegahan dan Penanggulangan Illegal, Unreported, and Unregulated Fishing Tahun 2012-2016; dan kelima, Peraturan Menteri Kelautan dan Perikanan No. PER.05/MEN/2008 tentang Usaha Perikanan Tangkap dan PERMA No. 01 Tahun 2007 tentang Peradilan Perikanan.

Transhipment adalah pemindahan muatan ikan yang terjadi di tengah lautan lepas. Menurut Business Dictionary, transhipment is transfer of a shipmentfrom one carrier, or morecommonly, from one vessel to another whe- 
reas in transit. ${ }^{19}$ Sampai saat ini belum ada peraturan di Indonesia yang mengatur transhipment secara khusus. Pengaturan mengenai transhipment yang ada sekarang biasanya merupakan bagian dari peraturan-peraturan tentang perikanan yang disisipkan dalam pasalpasal didalam peraturan tersebut. Pertama, Pasal 23 UU No 21 Tahun 2009 tentang Pengesahan Persetujuan Pelaksanaan Ketentuan-Ketentuan Konvensi PBB tanggal 10 Desember 1982 yang Berkaitan dengan Konservasi dan Pengelolaan Sediaan Ikan yang Beruaya Terbatas dan Sediaan Ikan yang Beruaya Jauh; kedua, Pasal 69 ayat (3) Peraturan Menteri Kelautan dan Perikanan Nomor 30 Tahun 2012 tentang Usaha Perikanan Tangkap di Wilayah Pengelolaan Perikanan Negara Republik Indonesia; ketiga, Keputusan Menteri Kelautan dan Perikanan Nomor KEP.50/MEN/2012 tentang Rencana Aksi Nasional Pencegahan dan Penanggulangan Illegal, Unreported, and Unregulated Fishing Tahun 2012-2016; keempat, pada Pasal 64 Peraturan Menteri Kelautan dan Perikanan Nomor PER.49/MEN/2011 tentang Perubahan Atas Peraturan Menteri Kelautan dan Perikanan Nomor PER.14/MEN/2011 Tentang Usaha Perikanan Tangkap; dan kelima, Pasal 30 Ayat (1) Peraturan Menteri Kelautan dan Perikanan Nomor PER.12/ MEN/2012 Tentang Usaha Perikanan Tangkap di Laut Lepas.

Analisis Isi Pasal 69 ayat (3): Tumpang Tindih Pengaturan Transhipment dalam Peraturan Hukum Indonesia

Isi Pasal 69 ayat (3) Peraturan Menteri Kelautan dan Perikanan Nomor 30 Tahun 2012 dapat dibagi menjadi tiga bagian. Pembagian ini didasarkan kepada konteks ragam bahasa tulis dalam ilmu hukum, yaitu: pertama, "Dalam pelaksanaan transhipment, ikan wajib didaratkan di pelabuhan pangkalan sesuai SIPI atau SIKPI"; kedua, "dan tidak dibawa keluar negeri"; dan ketiga, "kecuali bagi kapal penangkap ikan yang menggunakan alat penang-

19 Business Dictionary, 2013 tersedia di webside: http:// www.business dictionary.com/definitiontransshipment, diakses tanggal 12 Februari 2014. kapan ikan purse seine berukuran diatas 1000 (seribu) GT yang dioperasikan secara tunggal"

Isi Pasal 69 ayat (3) Peraturan Menteri Kelautan dan Perikanan Nomor 30 Tahun 2012 memiliki intepretasi ganda dan saling kontradiktif, yaitu pada bagian pertama menentukan bahwa dalam pelaksanaan transhipment, ikan wajib didaratkan di pelabuhan pangkalan sesuai SIPI atau SIKPI dan tidak dibawa keluar negeri. Bagian ini sudah sesuai dengan semangat Pasal 41 ayat (3) UU No. 45 Tahun 2009 perubahan UU No. 31 Tahun 2004 tentang Perikanan, menentukan bahwa

Setiap kapal penangkap ikan dan kapal pengangkut ikan harus mendaratkan ikan tangkapan di pelabuhan perikanan yang ditetapkan atau pelabuhan lainnya yang ditunjuk.

Namun, di bagian ketiga konten Pasal 69 ayat (3) Peraturan Menteri Kelautan dan Perikanan Nomor 30 Tahun 2012 menjadi bertentangan dengan menentukan:

kecuali bagi kapal penangkap ikan yang menggunakan alat penangkapan ikan purse seine berukuran diatas 1000 (seribu) GT yang dioperasikan secara tunggal.

Padahal pada ketentuan Pasal 41 ayat (3) UU No. 45 Tahun 2009 tidak disebutkan pengecualian. Hal ini jelas menunjukkan adanya pertentangan pengaturan yang lebih rendah (peraturan menteri) terhadap peraturan yang lebih tinggi (UU No. 45 Tahun 2009). Pernyataan dibagian ketiga dari konten Pasal 69 ayat (3) Peraturan Menteri Kelautan dan Perikanan Nomor 30 Tahun 2012 menggugurkan pernyataan dibagian kedua konten 69 ayat (3) tersebut. Hal ini sekaligus bertentangan dengan semangat Pasal 25B ayat (2) UU No. 45 Tahun 2009 yang menentukan bahwa:

Pengeluaran hasil produksi usaha perikanan ke luar negeri dilakukan apabila produksi dan pasokan di dalam negeri telah mencukupi kebutuhan konsumsi nasional.

Kondisi ini juga bertentangan dengan UU No. 18 Tahun 2012 tentang Pangan, dimana disebutkan dalam Pasal 34 ayat (1) dan ayat (2) bahwa: 
(1) Ekspor Pangan dapat dilakukan dengan memperhatikan kebutuhan konsumsi Pangan di dalam negeri dan kepentingan nasional.

(2) Ekspor Pangan Pokok hanya dapat dilakukan setelah terpenuhinya kebutuhan konsumsi Pangan Pokok dan Cadangan Pangan Nasional.

Berdasarkan perhitungan yang dilakukan Purnomo kebutuhan konsumsi masyarakat Indonesia terhadap ikan sebesar $34 \mathrm{~kg} / \mathrm{kapita} /$ tahun, maka dibutuhkan pasokan ikan konsumsi sebesar minimal 8,4 juta ton/tahun. ${ }^{20}$ Apabila dibandingkan dengan jumlah produksi ikan pertahun 6,5 juta ton/tahun. Fakta ini menjelaskan bahwa kebutuhan konsumsi pangan dalam negeri masihlah kurang sehingga apabila melakukan ekspor ataupun pengangkutan hasil ikan ke luar negeri, maka bertentangan dengan ketentuan UU.

Keberadaan kapal penangkap ikan yang menggunakan alat penangkapan ikan purse seine berukuran diatas 1000 GT yang dioperasikan secara tunggal di Indonesia berdasarkan data statistik perikanan dan kelautan tahun 2011 tidak ada. Bahkan berdasarkan lampiran Keputusan Menteri Kelautan dan Perikanan Nomor KEP.18/MEN/2011 tentang Pedoman Umum Minapolitan disebutkan Armada perikanan tangkap Indonesia di laut sebanyak 590.314 kapal, akan tetapi $94 \%$ berukuran kurang dari 5 GT dengan SDM berkualitas rendah dan kemampuan produksi rendah. Hal ini tentu berakibat pada rendahnya jumlah tangkap nelayan Indonesia. Kondisi ini jelas memperlihatkan bahwa keberadaan bagian ketiga konten Pasal 69 ayat (3) Peraturan Menteri Kelautan dan Perikanan Nomor 30 Tahun 2012 tidak didasarkan pada kondisi lapangan dan peraturan sebelumnya.

Akibat lain kondisi armada perikanan Indonesia itu adalah rendahnya kemampuan tangkap nelayan lokal, sedangkan berdasarkan Pasal 62 ayat (2) United Nations Convention on the Law of the Sea (UNCLOS) yang sudah diratifika-

20 Purnomo, A. H., Pangan dari Ikan: Kondisi Sekarang dan Prediksi Ke Depan. Seminar Hari Pangan Sedunia, Jakarta: 1 Oktober 2009. si Indonesia dalam UU No 17 Tahun 1985 menentukan bahwa:

Apabila terdapat sisa dari jumlah tangkap yang diperbolehkan yang tidak dimanfaatkan sepenuhnya oleh nelayan dan kapal penangkap ikan lokal di ZEE, pemerintah memberi kesempatan kepada nelayan atau kapal penangkap ikan negara lainnya untuk melakukan pemanfaatan sisa jumlah tangkapan yang diperbolehkan.

Artinya Pasal 69 ayat (3) Peraturan Menteri Kelautan dan Perikanan Nomor 30 Tahun 2012 bertentangan dengan Pasal 33 ayat (3) Amandemen UUD 1945, yang menentukan bahwa bumi dan air dan kekayaan alam yang terkandung didalamnya dikuasai oleh negara dan dipergunakan untuk sebesar-besar kemakmuran rakyat.

Konten Pasal 69 ayat (3) Peraturan Menteri Kelautan dan Perikanan Nomor 30 Tahun 2012 jelas-jelas berseberangan dengan Keputusan Menteri Kelautan dan Perikanan Nomor KEP.50/MEN/2012 tentang Rencana Aksi Nasional Pencegahan dan Penanggulangan Illegal, Unreported, and Unregulated Fishing Tahun 2012-2016. Pada lampiran peraturan tersebut dijelaskan bahwa ada sejumlah praktik-praktik kegiatan perikanan tidak dilaporkan (Unreported Fishing) dan rawan tindakan ilegal, yaitu: pertama, pemindahan hasil tangkapan di tengah laut atau sea transhipment tanpa didata/ dilaporkan kepada aparat yang berwenang; kedua, para pelaku tidak melaporkan hasil tangkapannya, untuk menghindari pembayaran pungutan atas usaha yang dilakukan; ketiga, kapal penangkap ikan dan kapal pengangkut ikan tidak melapor di pelabuhan pangkalan kapal sesuai izin yang diberikan; dan keempat, kapal penangkap ikan langsung dari laut membawa ikan hasil tangkapan ke luar negeri. Keempat modus menandakan kontra produktifnya klausul alih muatan (transhipment) dengan upaya memberantas praktik pencurian di laut.

Pasal 23 UU No 21 Tahun 2009 tentang Pengesahan Persetujuan Pelaksanaan Ketentuan-Ketentuan Konvensi PBB tanggal 10 Desember 1982 yang Berkaitan dengan Konservasi dan Pengelolaan Sediaan Ikan yang Beruaya Terba- 
tas dan Sediaan Ikan yang Beruaya Jauh, menentukan:

Negara dapat membuat peraturan-peraturan yang memberikan kewenangan kepada otoritas nasional yang terkait un-tuk melarang pendaratan dan tranship-ment apabila telah ditentukan bahwa tangkapan telah diambil dengan cara yang mengurangi efektivitas tindakan konservasi dan pengelolaan sub regional, regional, atau global di laut lepas.

Pasal tersebut memberi arti bahwa pemerintah seharusnya tidak membuat peraturan yang memberikan izin untuk transhipment dikondisi krisis perikanan akibat maraknya praktek IUU Fishing di Indonesia.

Di satu sisi terdapat juga pemerintah yang membuat peraturan dengan membolehkan ada-nya transhipment, yaitu Peraturan Menteri Kelautan dan Perikanan Nomor PER.49/MEN/ 2011 tentang Perubahan Atas Peraturan Menteri Kelautan dan Perikanan Nomor PER.14/MEN/ 2011 Tentang Usaha Perikanan Tangkap. Pasal 64 dalam peraturan tersebut menyebutkan bahwa "Pemindahan dan/atau penerimaan ikan hasil tangkapan ikan di daerah penangkapan atau transhipment dilarang, kecuali: pertama, kapal pe-nangkap ikan tuna long line atau hand line dalam satu kesatuan manajemen usaha, dengan ketentuan wajib didaratkan di pelabuhan pangkalan yang tercantum dalam Surat Izin Penangkapan Ikan (SIPI) atau Surat Izin Kapal Penangkap Ikan (SIKPI); dan kedua, kapal penangkap ikan berukuran 10 (sepuluh) GT ke bawah ke kapal pengangkut ikan yang menjadi mitranya di wilayah sentra nelayan yang tercantum dalam SIKPI dan mendaratkan ikannya di pelabuhan pangkalan yang tercantum dalam SIKPI. Peraturan ini memperbolehkan aktivitas transhipment khusus untuk penangkap ikan tuna long line atau hand line, dan dengan menggunakan kapal penangkap ikan berukuran 10 (sepuluh) GT ke bawah, serta didaratkan di wilayah sentra nelayan atau pelabuhan pangkalan. Hal ini tentu berbeda dengan ketentuan Pasal 69 ayat (3) Peraturan Menteri Kelautan dan Perikanan Nomor 30 Tahun 2012 yang membolehkan kapal penangkap ikan yang menggunakan alat penangkapan ikan purse seine berukuran diatas
1000 (seribu) GT yang dioperasikan secara tunggal dan dapat juga dibawa ke luar negeri.

Pada peraturan lain (Peraturan Menteri Kelautan dan Perikanan Nomor PER.12/MEN/ 2012 Tentang Usaha Perikanan Tangkap di Laut Lepas) transhipment diizinkan pada bagian dari laut yang tidak termasuk dalam ZEEI, laut teritorial Indonesia, perairan kepulauan Indonesia, dan perairan pedalaman Indonesia atau yang dikenal dengan laut lepas. Pada Bab VIII, Pasal 30 ayat (1) disebutkan Kapal penangkap ikan dapat melakukan transhipment di laut lepas maupun di pelabuhan di negara lain yang menjadi anggota (Regional Fisheries Manage-ment Organization) RFMO pada wilayah RFMO yang sama.

Berdasar pemaparan di atas dapat disimpulkan bahwa Pasal 69 ayat (3) Peraturan Menteri Kelautan dan Perikanan Nomor 30 Tahun 2012 bertentangan dengan asas-asas hukum yang ada yaitu: UU yg dibuat oleh penguasa yg lebih tinggi, mempunyai kedudukan yang lebih tinggi pula, lex specialis derogat lex generalis, lex posteriore derogat lex priori, UU sebagai sarana untuk semaksimal mungkin dapat mencapai kesejahteraan spiritual dan material bagi masyarakat maupun individu, melalui pembauharuan atau pelestarian (asas welvaarstaat).

Selain itu, bila dilihat dari teori keberlakukan UU yang dinyatakan oleh Gustav Radbruch, Pasal 69 ayat (3) Peraturan Menteri Kelautan dan Perikanan Nomor 30 Tahun 2012 tidak memenuhi unsur keadilan dilihat dari pengecuali melakukan transhipment bagi kapal penangkap ikan yang menggunakan alat penangkapan ikan purse seine berukuran diatas 1000 (seribu) GT yang dioperasikan secara tunggal. Ditambah lagi dengan kenyataan bahwa yang memiliki kapal dengan kemampuan 1000 (seribu) GT adalah negara asing. Kedua, unsur kepastian hukum, tidak adanya sinkronisasi antara peraturan yang satu dengan peraturan yang lainnya, serta tidak adanya pasal dan peraturan lain yang menjelaskan lebih detail mengenai Pasal ini tentunya menimbulkan ketidakpastian hukum dalam penegakan hukum. Ketiga, unsur kemanfaatan, dilihat dari kondisi peralatan tangkap Indonesia saat ini, 
dan belum terpenuhinya kebutuhan ikan nasional, maka bias disimpulkan Pasal 69 ayat (3) Peraturan Menteri Kelautan dan Perikanan No. 30 Tahun 2012 tidak memenuhi unsur kemanfaatan bagi kepentingan masyarakat Indonesia pada khususnya.

Teori perlindungan laut Selden yang dikenal dengan teori mare clausum, yang berpandangan bahwa suatu saat sumber kekayaan laut akan habis bila tidak dimanfaatkan secara bertanggung jawab juga tidak menjiwai pemberlakukan Pasal 69 ayat (3) Peraturan Menteri Kelautan dan Perikanan Nomor 30 Tahun 2012. Hal ini disebabkan karena pemberian izin transshipment di tengah laut bagi kapal penangkap ikan yang menggunakan alat penangkapan ikan purse seine berukuran diatas 1000 (seribu) GT tidak diatur lebih detail lagi mengenai kewajiban yang harus dilakukan sebagai akibat pengecualian tersebut memungkinkan terjadinya praktek IUU Fishing. Itu sama artinya dengan pemberian peluang pemanfaatan sumber kekayaan laut secara tidak bertanggungjawab.

\section{Penutup}

Simpulan

Hasil kajian ini menggungkapkan bahwa penerapan Pasal 69 ayat (3) Peraturan Menteri Kelautan dan Perikanan Nomor 30 Tahun 2012 tentang Usaha Perikanan Tangkap di Wilayah Pengelolaan Perikanan Negara Republik Indonesia terhadap Perikanan Laut Indonesia membeorikan peluang yang semakin besar untuk terjadinya praktek IUU Fishing di perairan Indonesia oleh kapal asing. Hal ini dikarenakan klasifikasi kapal yang bisa melakukan transshipment ditengah laut dan dibawa langsung keluar negeri adalah kapal penangkap ikan yang menggunakan alat penangkapan ikan purse seine berukuran diatas 1000 (seribu) GT yang dioperasikan secara tunggal sampai saat ini hanya dimiliki oleh asing, bukan nelayan Indonesia. Pasal inipun seperti berdiri sendiri karena tidak ada pengaturan lebih lanjut, baik dalam Peraturan Meteri tersebut maupun peraturan lainnya. Malah keberadaan Pasal ini tumpang-tindih terhadap peraturan lainnya.

\section{Saran}

Perlu dilakukan revisi terhadap penerapan Pasal 69 Peraturan Menteri Kelautan dan Perikanan Nomor 30 Tahun 2012 tentang Usaha Perikanan Tangkap di Wilayah Pengelolaan Perikanan Negara Republik Indonesia tersebut karena tidak sesuai dengan teori keberlakukan Undang-Undang oleh Gustav Radbruch yaitu keberlakukan suatu peraturan harus mengandung unsur kemanfaatan, kepastian hukum dan keadilan, asas-asas hukum Purnadi Purbacaraka dan Soerjono Soekanto dan teori perlindungan laut Selden. Serta perlu dilakukannya suatu kajian yang mendalam dalam penetapan suatu peraturan perundang-undangan agar tidak ada lagi tumpang tindih peraturan yang satu dengan peraturan yang lainnya.

\section{Daftar Pustaka}

A. H. Purnomo. Pangan dari Ikan: Kondisi Sekarang dan Prediksi ke Depan. Seminar Hari Pangan Sedunia. Jakarta, 1 Oktober 2009;

Baird, Rachel. "Illegal. Unreported and Unregulated Fishing: An Analysis of The Legal. Economic and Historical Factors Relevant to its Development and Persistence". Melbourne Journal of International Law. Vol 5 Tahun 2004. Melbourne: University of Melbourne;

Éva dan Markus Burgener. "Illegal and unreported fishing on abalone-Quantifying the extent using a fully integrated assessment model". Fisheries Research. Vol. 107 (2011). Elsevier B.V;

Fink-Hafner. D. "The Political Instrumentalisation of Policy Analysis". Journal Politicka Misao: Croatian Political Science Review. Vol 48 No. 5. Tahun 2011. Croatian: Faculty of Policital Science University of Zagreb;

Gustina, Amelya. "Pentingnya Pemberantasan Illegal. Unreported and Unregulated (IUU) Fishing Guna Mendukung Pembangunan Wi-layah Laut Berkelanjutan". Jurnal Bina Adhyaksa. Vol. 3 No. 3 Edisi Juli 2013. Jakarta: Puslitbang Kejaksaan Agung RI;

Karim, Muhamad. "Partisipasi Daerah dalam Mengantisipasi Ancaman Perubahan Iklim Bagi Eksistensi Pulau-pulau Kecil Ter- 
luar". Jurnal Pembangunan Daerah. Vol 2009 No. 03 Edisi September 2009. Jakarta: Dirjen Bina Pembangunan Daerah Departemen Dalam Negeri;

Kusumo Satriyo A,T,. "Optimalisasi Pengelolaan dan Pemberdayaan Pulau-pulau Terluar dalam Rangka Mempertahankan Keutuhan Negara Kesatuan Republik Indonesia". Jurnal Dinamika Hukum. Vol 10 No. 3. Edisi September 2010. Purwokerto: Fakultas Hukum Universitas Jenderal Soedirman;

Lasabuda, Ridwan. "Pembangunan Wilayah Pesisir dan Lautan dalam Perspektif Negara Kepulauan Republik Indonesia'. Jurnal Ilmiah Platax. Vol 1-2. Edisi Januari 2013. Fakultas Perikanan dan Ilmu Kelautan Universitas Sam Ratulangi;

Ndiaye, Tafsir Malick. "Illegal. Unreported and Unregulated Fishing: Responses in General and in West Africa". Chinese Journal of International Law (2011). Oxford: Oxford University Press;

Petak. Z. \& Petek. A. "Policy Analysis and Croatian Public Administration: The Problem of Formulating Public Policy". Journal Politicka Misao: Croatian Political Science Review. Vol 46 No. 5. Tahun 2009. Croatian: Faculty of Policital Science University of Zagreb;

Putera, Prakoso B. "Perspektif Sistem Inovasi dalam Konten Kebijakan Daerah Jawa Timur Bidanglptek dan Inovasi. Periode 2000-2011". Jurnal "Warta Kebijakan Iptek dan Manajemen Litbang". Vol 10 No. 2. Edisi Desember Tahun 2012. Jakarta: Puslit Perkembangan Ilmu Pengetahuan dan Teknologi Lembaga Ilmu Pengetahuan Indonesia;

Putera, Prakoso B. "Perspektif dan Peran IImu Pengetahuan dan Teknologi dalam Membangunan Kemandirian Bangsa Pada Tatanan Negara Maritim". Inovasi: Jurnal Poli-tik dan Kebijakan. Vol 10 No. 2 Edisi Juni 2013. Medan: Balitbang Provinsi Sumatera Utara;

Putera, Prakoso B. dan Jannah, Lina M. "Science \& Technology and Innovation Policies in Science \& Technological Research. Development. and Implementation". International Journal of Administrative Science \& Organization. Vol 19 No. 2. Edisi September. Tahun 2012. Depok: Departemen Ilmu Administrasi Universitas Indonesia;
Sodik, Dikdik Mohamad. "IUU Fishing and Indonesia's Legal Framework for Vessel Registration and Fishing Vessel Licensing". Ocean Development \& International Law. Vol 40 Issue 3. 2009. Taylor \& Francis Online;

Tsamenyi, Martin. Et.al. "The European Council Regulation on Illegal. Unreported and Unregulated Fishing: An International Fisheries Law Perspective". The Internatio-nal Journal of Marine and Coastal Law. Vol 25 (2010). Leiden: Koninklijke Brill NV;

Zakaria, Alfons. "Imprisonment for IUU Fishing in Indonesia's Exclusive Economic Zone: Why it Should Not Be Imposed". Jurnal "Arena Hukum". Vol 6 No. 2. Edisi Agustus 2012. Malang: Fakultas Hukum. Universitas Brawijaya. 